\title{
Urban organic farming in Austria with the concept of Selbsternte ('self-harvest'): An agronomic and socio-economic analysis
}

\author{
Christian R. Vogl ${ }^{\star}$, Paul Axmann, and Brigitte Vogl-Lukasser \\ Institute for Organic Farming, University for Natural Resources and Applied Life Sciences Vienna, Gregor \\ Mendel Strasse 33, A-1180 Vienna, Austria. \\ *Corresponding author: vogl@edv1.boku.ac.at
}

\begin{abstract}
In Vienna, consultants, organic farmers and green-minded consumers have developed a new concept of urban organic farming, called Selbsternte ('self-harvest'). Organic farmers prepare a plot of arable land (the Selbsternte plot) and sow or plant rows composed of 18-23 plant species. In mid-May the plots are divided into subplots that contain $2-6 \mathrm{~m}$ of every sown species and are rented to so-called self-harvesters for a period of about 136 days. In 2002 Selbsternte was being practiced at 15 plots in Vienna or in neighboring cities, represented by 861 subplots, with a total area of $68,740 \mathrm{~m}^{2}$, and managed by 12 organic farmers for 861 registered self-harvesters. At the Roter Berg plot, experimental subplots were established to evaluate yields and the value of the harvested produce, and interviews were conducted with 27 self-harvesters, the eight Selbsternte farmers and one Selbsternte consultant. The experimental subplots were managed in two different ways, namely, 'with low intensity' (LIS) and 'with high intensity' (HIS; meaning additional harrowing, mulching and sowing of additional plants). At the LIS $24.2 \mathrm{~h}$ and at the HIS $38.9 \mathrm{~h}$ of work were invested over 51 days. Monetary investment was US\$184 for the LIS and US\$259 for the HIS subplots. The total harvest of fresh produce was: $163 \mathrm{~kg} \mathrm{subplot}^{-1}$ for LIS and $208 \mathrm{~kg} \mathrm{subplot}^{-1}$ for HIS subplots. The total value of the harvest at the HIS was US\$364 for conventional and US\$766 for organic prices. All self-harvesters saw the rental of a subplot and the work as an activity of leisure. More than half of the self-harvesters reported 'trying something new' at their subplots. The most frequently mentioned innovation for them was growing an unknown species. Twenty-five self-harvesters sowed 54 different, additional plant species. The motivating factors in establishing Selbsternte plots, as reported by all the farmers, were, primarily, better relations with consumers and work diversification, and only then were economic factors a consideration. The contribution of Selbsternte to income varied at the farms, being between 0 and $30 \%$ of the total farm income. As a main success factor, all of the farmers reported a close relationship between the self-harvesters and the farmers. Selbsternte subplots can be understood as small experimental stations where self-harvesters merge traditional horticultural techniques with urban ideas on permaculture, sustainable land use and participatory farming. Selbsternte has potential value for the improvement of urban agriculture, but also for the development of organic farming in general.
\end{abstract}

Key words: urban farming, organic farming, agrobiodiversity, innovation, self-harvesters relations, farmers' experiments

\section{Introduction}

Cities like Vienna (Austria) are known for their great monuments and wonderful fine arts. At first glance, Viennese urban agriculture seems to be limited to public baroque gardens, vineyards, allotments (Schrebergärten) and intensive vegetable cultivation in the district called
Simmering. But recently, consultants, organic farmers and green-minded self-harvesters have developed a new concept of urban organic farming, called Selbsternte ('selfharvest'), which allows new types of interaction between organic farmers and urban citizens in residential areas. The aim of this paper is to describe the concept, to characterize the self-harvesters and organic farmers involved, to assess 
the agronomic and socio-economic benefits and the possible constraints of the concept, and to develop hypotheses for further research.

The effort to extend urban farming in Vienna parallels similar efforts in other countries worldwide. The worldwide trend towards urbanization and the pressure to develop agricultural land in cities and their peripheries into new residential areas, industrial facilities or shopping malls has led to counter efforts. Such efforts aim to safeguard green urban areas by designating at least some of them for agricultural use ${ }^{1,2}$.

About 800 million people farm in urban settings worldwide $^{3}$. The farmers, consumers, urban planners and scientists dealing with urban farming expect this kind of urban land use to lead to better food security, nutrition and health, to improve the social development of neighborhoods, and to raise the sustainability of cities by reducing their ecological footprint ${ }^{4-6}$. Urban farming is not only promoted in developing countries but also in cities like New York $^{7}$, Berlin $^{8}$, Tokyo ${ }^{9}$, London ${ }^{10}$ and Vienna (see below), where these positive effects also are expected. Some authors believe that using organic practices increases the sustainability of urban agriculture ${ }^{11,12}$.

\section{The concept of Selbsternte}

When utilizing the Selbsternte system, organic farmers (organic in accordance with European Council Regulation No. 2092/91) prepare a parcel of arable land in the urban area, owned by themselves or rented to them by a third party, by tillage, fertilization and construction of fencing and irrigation facilities. The shape of this piece of land for Selbsternte is usually rectangular and it is herein called a Selbsternte plot (Fig. 1). At their Selbsternte plots, the farmers sow or plant rows with different vegetable species, subspecies or varieties, all referred to henceforth as species. Eighteen to twenty-three species can be found at these Selbsternte plots. Between 1 and 4 rows are sown for each species. In mid-May, the plots are divided into subplots of 20, 40, 60 or $80 \mathrm{~m}^{2}$ (Fig. 1, Fig. 2). Subplots are situated with the longer edge of the subplot in a pattern perpendicular to the direction of the rows, so that each subplot contains 2-6 m of every sown species, or more in cases when one species is grown in more than one row (see an example of a subplot and its species in Fig. 2). Then subplots are rented to self-harvesters for between US\$73 and US\$182 (calculation based upon the exchange rate: 1 euro $=1$ US\$) in total, for the time between May and October. The price of the rental fee depends on the size of the subplot and the additional management offered by the farmer (irrigation, weeding, winter storage of produce, additional plots for flowers and spices, etc.). In November the self-harvesters have to leave the subplots and the organic farmers proceed with soil management for succeeding agricultural crops or for the next Selbsternte period.

The sequence of work (Fig. 3) as described above is called Selbsternte, literally: 'harvest by ourselves'. But

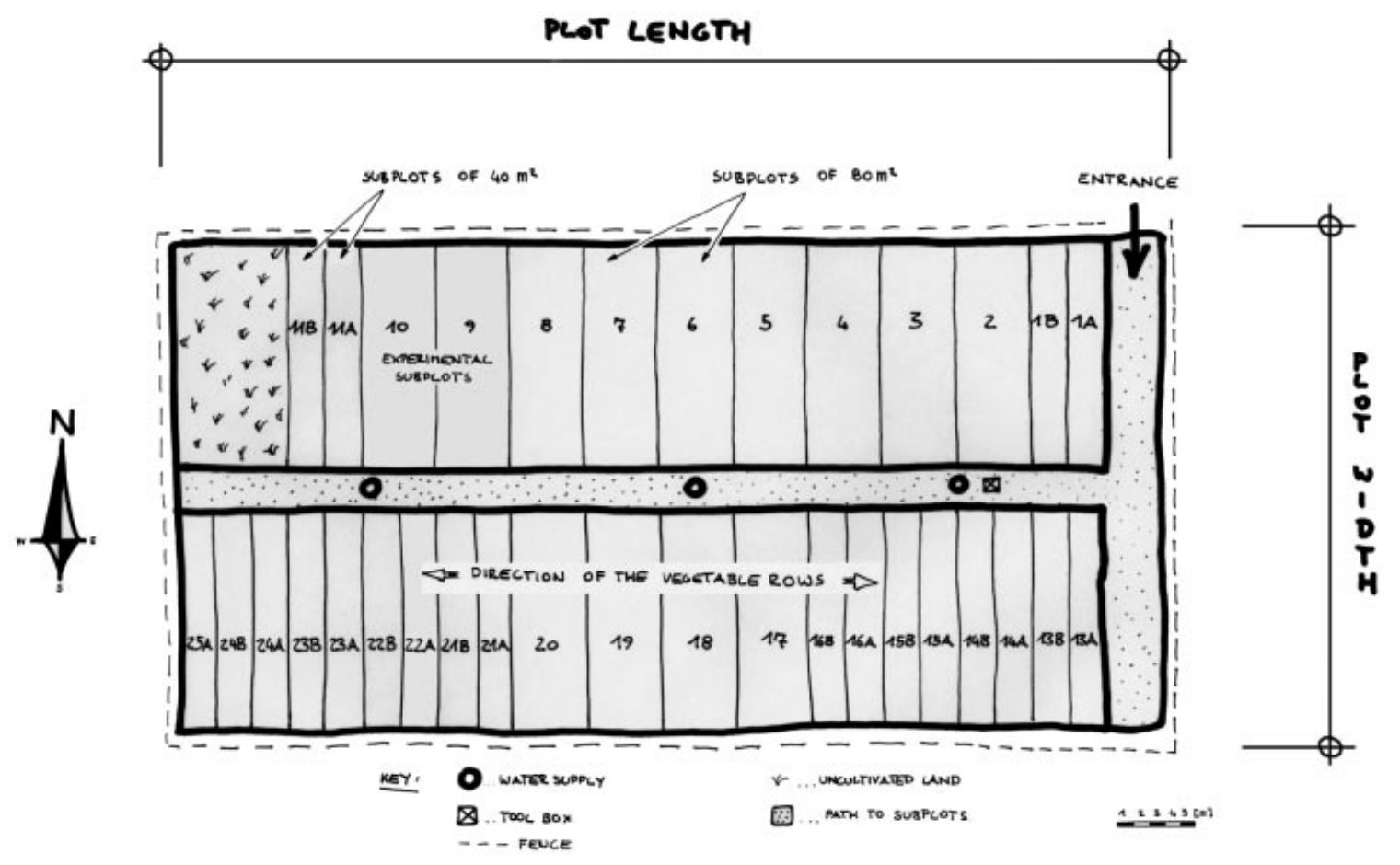

Figure 1. The Selbsternte plot Roter Berg, Vienna, with the self-harvesters' subplots of different size $\left(40 \mathrm{~m}^{2}, 80 \mathrm{~m}^{2}\right)$ and the two experimental subplots (subplot 10, managed with high intensity, HIS; and subplot 9, managed with low intensity, LIS). Plant species were sown from right to left and vice versa. 


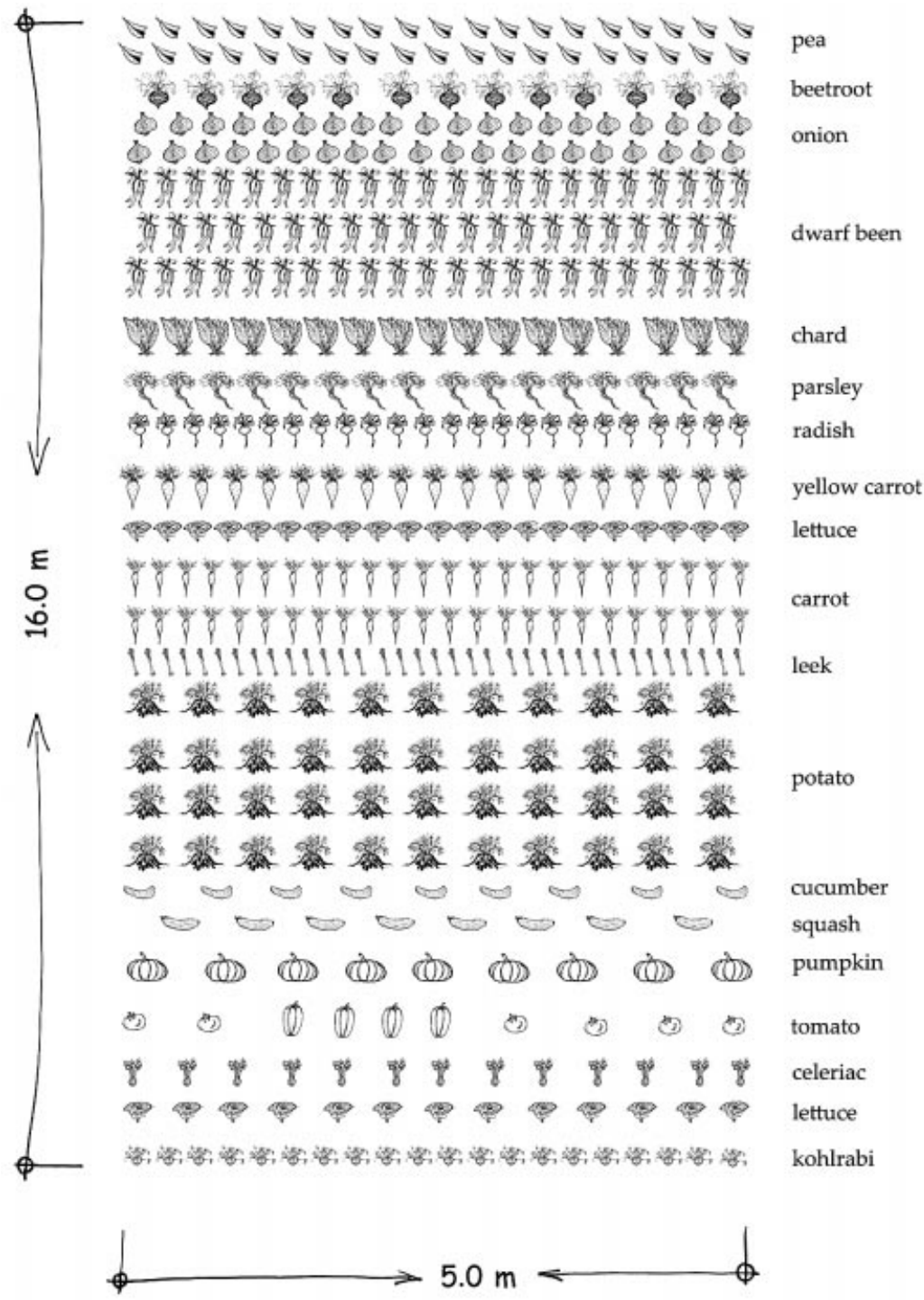

Figure 2. A scheme of a Selbsternte subplot as rented by a self-harvester with the choice of plant species usually sown/planted by Selbsternte farmers.

Selbsternte is not only the technical term for the concept; it is also a registered $\log o$ and text trade mark for the Selbsternte company that provides the Selbsternte trade label to farmers and that supports all participating farmers and self-harvesters with necessary technical information. Consultants of the Selbsternte company advertise the concept, and are engaged in the organization of courses for self-harvesters on organic farming, on healthy cooking and on several related topics. Farmers using the trade mark and receiving consultancy pay an annual license fee (between US\$185 and US\$810, depending on the number of the subplots) to the Selbsternte company.

\section{A brief history of how the idea spread}

The first Selbsternte plot was established by the organic farmer Rudolf Hascha in Rothneusidel (10th District of Vienna) in 1987. He obtained support for his idea from the
Department for Environmental Advice (Mrs Bruno, Environmental Advisory Service) in Vienna. As a result of the farmers' and self-harvesters' positive experience, the Municipality of Vienna decided to establish another Selbsternte plot at the municipal farm Schafflerhof. Due to intense public relations activity, even more plots were established by other farmers between 1994 and 1996.

Mrs Bruno and Mr Resch, an organic farmer, founded the company Selbsternte in 1998 to fully support the idea. The company itself started to manage Selbsternte plots. Since 2002, the Municipal Department for Gardens and Parks (MA 49) and teachers and students of the technical school for gardening in Vienna (Gartenbauschule Schönbrunn) have been supporting the management of some plots.

Recently, the University of Kassel-Witzenhausen in Germany learned of the concept. They established plots at their experimental farm and advertised the concept. As a 


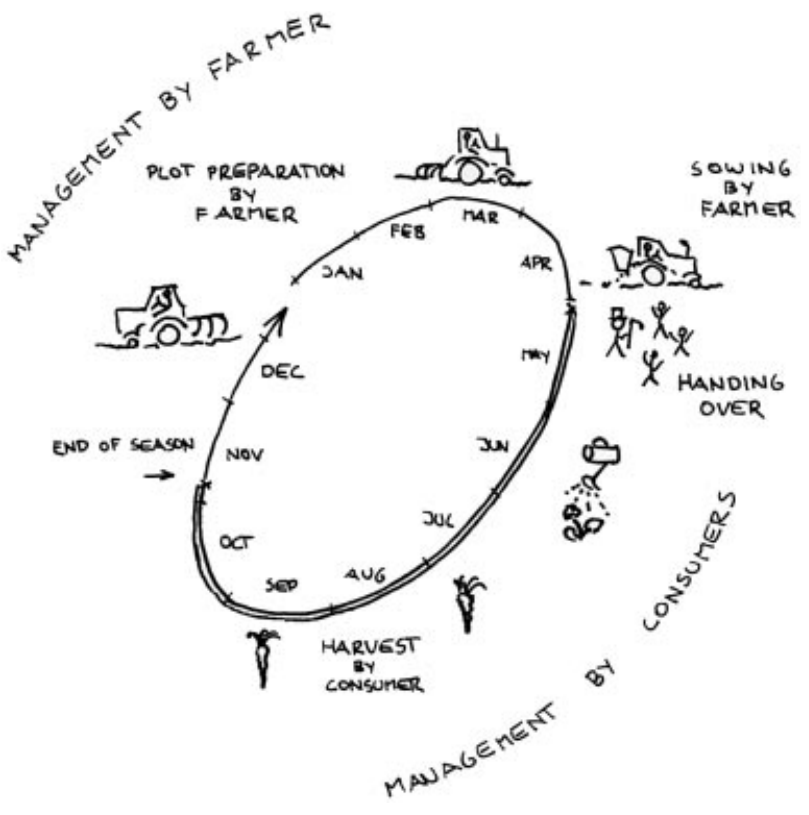

Figure 3. The Selbsternte yearly life cycle.

consequence, several organic farmers in the region around Witzenhausen also started establishing plots, supervised by this university ${ }^{13,14}$. In Munich, Germany, city authorities also started applying the concept, but did so under a different name.

In 2002 Selbsternte was being practiced at 15 plots in Vienna or in neighboring cities, represented by 861 subplots, with a total area of $68,740 \mathrm{~m}^{2}$ and managed by 12 organic farmers for 861 registered self-harvesters (Table 1). The actual area of the plots is larger than the total of the area of the subplots, because all of the farmers offer additional areas for recreation, i.e., lawn, tables and benches, and playgrounds within their plots. The actual number of self-harvesters working in subplots is larger than the number of registered self-harvesters, because all registered self-harvesters work together with friends and relatives at the subplots.

\section{Methods}

To assess the benefits and constraints of the Selbsternte concept, experimental subplots were established to evaluate the yields and net profit for the self-harvesters, and interviews were conducted with the self-harvesters, the Selbsternte farmers and one Selbsternte consultant.

\section{Survey at the experimental subplots}

Two subplots (Fig. 1) at the Selbsternte plot Roter Berg were managed between May and October 2001. The experimental management started on May 18, 2001, when all subplots were handed over to the self-harvesters, and ended on October 31, 2001, when subplots had to be returned to the farmer.
The site of this experiment has been used since 1999 for Selbsternte plots. Precipitation is $613 \mathrm{~mm} \mathrm{year}^{-1}$ and the annual mean temperature is $9.9^{\circ} \mathrm{C}$. In 2001 the plot had a size of $3000 \mathrm{~m}^{2}$ and was divided into 13 subplots of $80 \mathrm{~m}^{2}$ and 21 subplots of $40 \mathrm{~m}^{2}$. Twenty plant species (Table 2) were sown on May 2, 2001, or planted on May 17, 2001, by the Selbsternte farmer at this site. According to the Selbsternte consultant, plowing at Roter Berg was done during an inappropriate period of excessively humid soil conditions, and sowing was done subsequently in a period of very dry conditions. Both the plowing and sowing were done in this manner due to coordination problems and time pressure encountered during the project. As a consequence, the consultant viewed the performance of the plants (time until ground cover, yields) at this plot as worse than in previous years and worse in comparison to other plots.

The experimental subplots were managed in two different ways: with low and with high intensity-representing both the gradations of the 'intensity' factor-at two different subplots. We call them the low-intensity subplot (LIS) and the high-intensity subplot (HIS).

Work was done on the LIS subplot in a manner equivalent to that of the average self-harvester at Roter Berg. Some self-harvesters at Roter Berg took extra care with their subplots and introduced practices such as harrowing, mulching and sowing of additional plants. To represent this type of self-harvester, these activities were also performed on the HIS subplot. As a consequence, irrigation with hosepipes, weeding and the manual control of pests and diseases (manual collecting of pests and of infested plant organs) were done in the same way and with the same intensity in both the LIS and the HIS subplots. Additionally, in the HIS subplot: (1) soil was harrowed six times between rows; (2) the soil was mulched five times with cut and dried weeds pulled from the paths; and (3) additional plants were sown or planted between May and October. These additional plants consisted of individuals of the species already present, i.e., species sown or planted by the farmer, and individuals of species new to the plot, i.e., species introduced by the self-harvesters.

During management, inputs (cash to cover the necessary costs, duration of work) and the output (fresh weight of all harvested produce) were surveyed on data sheets. Only those costs related directly to the management of the subplot were recorded (rental fee, cost of seeds and plantlets, materials necessary to manage the subplot), i.e., neither the cost of transport incurred in buying necessary inputs, harvest processing costs nor cooking costs were recorded. Duration of work was recorded in the categories of sowing, planting, weeding, harrowing, mulching, irrigating, weeding, management of plants (e.g., trellising, controlling pests and diseases) harvesting and the cleaning of harvested produce. The recording of time started when an activity actually began, and ended when the activity actually stopped. The time for breaks from the activities, e.g., when spontaneous conversation with neighbors occurred, was not included in the calculation. 
Table 1. Selbsternte plots in Austria and their characteristics in 2002.

\begin{tabular}{|c|c|c|c|c|c|c|c|c|}
\hline Location of plots & Province & $\begin{array}{c}\text { Year when } \\
\text { activity } \\
\text { started }\end{array}$ & $\begin{array}{c}\text { Total } \\
\text { area }\left(\mathbf{m}^{2}\right) \\
\text { of subplot }\end{array}$ & $\begin{array}{c}\text { Number of } \\
\text { subplots } \\
\left(80 \mathrm{~m}^{2} \text { per }\right. \\
\text { subplot })\end{array}$ & $\begin{array}{l}\text { Plant } \\
\text { species } \\
\text { sown }\end{array}$ & $\begin{array}{l}\text { Species sown } \\
\text { by farmer in } \\
\text { addition to } \\
\text { those at subplot }^{3}\end{array}$ & $\begin{array}{l}\text { Service offered } \\
\text { by farmer }\end{array}$ & $\begin{array}{l}\text { Range of fees } \\
\text { to be paid for } \\
\text { subplots }{ }^{4} \text { of } \\
\text { different size (US\$) }\end{array}$ \\
\hline Asperhofen & Lower Austria & 1998 & 240 & 3 & 22 & Spices and medicines & Sowing and irrigation & $75 / 150$ \\
\hline Höbersdorf & Lower Austria & 1998 & 1440 & 18 & 18 & Spices & Sowing & $87 / 140$ \\
\hline Mödling ${ }^{I}$ & Lower Austria & 1998 & 5120 & 64 & 22 & Spices and ornamentals & Sowing & $100 / 182$ \\
\hline Schwadorf & Lower Austria & 2002 & 480 & 6 & 22 & None & Sowing & $75 / 140$ \\
\hline Tribuswinkel & Lower Austria & 2001 & 2000 & 25 & 22 & Spices & Sowing and irrigation & $90 / 167$ \\
\hline Frauenhofen & Lower Austria & 1994 & 960 & 12 & 22 & Spices & Sowing and irrigation & $125 / 65$ \\
\hline Rothneusiedl & Vienna & 1987 & 32,000 & 400 & 23 & None & Sowing and irrigation & $109 / 55$ \\
\hline Siebenhirten & Vienna & 1996 & 6400 & 80 & 19 & None & Sowing and irrigation & $73 / 124$ \\
\hline Erlaa & Vienna & 1995 & 4800 & 60 & 19 & None & Sowing and irrigation & $73 / 124$ \\
\hline Hirschstetten & Vienna & 2000 & 8000 & 100 & 20 & Strawberries & Sowing and irrigation & $87 / 145$ \\
\hline Hietzing $\mathrm{RB}^{l}$ & Vienna & 1999 & 1880 & 24 & 22 & None & Sowing & $100 / 182$ \\
\hline Hietzing JPG ${ }^{l}$ & Vienna & 2000 & 2800 & 35 & 22 & None & Sowing & $100 / 182$ \\
\hline Alkoven & Upper Austria & 1995 & 800 & 10 & 22 & None & Sowing and irrigation 5 & $100 / 180$ \\
\hline Breitenau & Lower Austria & 2000 & 960 & 12 & 22 & Spices & Sowing & $100 / 162$ \\
\hline Zettling-Graz & Styria & 1999 & 820 & 12 & 19 & Ornamentals & Sowing and irrigation & $100 / 145 / 180$ \\
\hline Total: 15 plots & 4 provinces & - & 68,740 & 861 & $18-23$ & - & - & $73-182$ \\
\hline
\end{tabular}

${ }^{I}$ Plots managed by the Selbsternte company (RB, Roter Berg; JFP, Josef Pommer Gasse, Mödling-St. Gabriel); other plots managed by different organic farmers.

2 The plot is larger than the total area of subplots, because it includes areas for paths, toolboxes, irrigation facilities and usually also an area with a lawn for recreation.

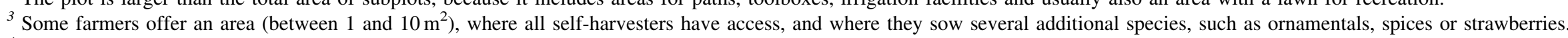

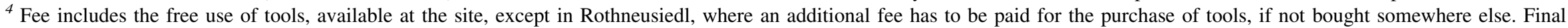

fee depends of the size of the subplot and the additional services requested by the self-harvesters/offered by the farmers.

${ }^{5}$ Several additional services available upon additional fee (weeding, planting of additional species, etc.). 
Table 2. Plants sown or planted by the Selbsternte farmer at all subplots [low intensity (LIS) and high intensity (HIS)] and in the HIS subplot at the Selbsternte plot Roter Berg,Vienna, with their yields in $\mathrm{kg} \operatorname{subplot}^{-1}$ (subplot $=80 \mathrm{~m}^{2}$ ).

\begin{tabular}{|c|c|c|c|c|c|}
\hline \multirow[b]{3}{*}{ Scientific name } & \multirow[b]{3}{*}{ English name } & \multicolumn{4}{|c|}{ Yield (kg subplot ${ }^{-1}$ ) } \\
\hline & & LIS & HIS & HIS & HIS \\
\hline & & $\begin{array}{l}\text { Species sown } \\
\text { by farmer }\end{array}$ & $\begin{array}{l}\text { Species sown } \\
\text { by farmer }\end{array}$ & $\begin{array}{l}\text { Additional } \\
\text { individuals }\end{array}$ & $\begin{array}{l}\text { Additional } \\
\text { species }\end{array}$ \\
\hline Allium cepa var. сера & Onion & 3.34 & 3.14 & 4.20 & $\mathrm{x}$ \\
\hline Allium porrum var. porrum & Leek & 2.32 & 2.33 & - & $\mathrm{x}$ \\
\hline Apium graveolens var. rapaceum & Celeriac & 1.95 & 1.62 & - & $\mathrm{x}$ \\
\hline Beta vulgaris ssp. vulgaris convar. cicla var. cicla & Swiss chard & 22.07 & 16.19 & 3.30 & $\mathrm{x}$ \\
\hline Beta vulgaris ssp. vulgaris convar vulgaris var. vulgaris & Beetroot & 8.81 & 4.4 & - & $\mathrm{x}$ \\
\hline $\begin{array}{l}\text { Brassica oleracea ssp. oleracea convar. caulorapa var. } \\
\text { gongylodes }\end{array}$ & Kohlrabi & 1.14 & 2.11 & - & $\mathrm{x}$ \\
\hline Capsicum аппиит & Peppers & 0.99 & 0.72 & - & $\mathrm{x}$ \\
\hline Cucumis sativus & Cucumber & 4.76 & 2.42 & - & $\mathrm{x}$ \\
\hline Cucurbita moschata & Pumpkin & 12.66 & 13.73 & - & $\mathrm{x}$ \\
\hline Cucurbita pepo & Zucchini & 33.84 & 31.26 & - & $\mathrm{x}$ \\
\hline Daucus carota ssp. sativus & Carrots & 15.15 & 14.49 & 0.42 & $\mathrm{x}$ \\
\hline Lactuca sativa var. capitata & Iceberg lettuce & 0.76 & 1.22 & - & $\mathrm{x}$ \\
\hline Lactuca sativa var. crispa & Lettuce & 0.74 & 0.87 & - & $\mathrm{x}$ \\
\hline Lycopersicon esculentum var. esculentum & Tomato & 11.48 & 9.18 & 6.91 & $\mathrm{x}$ \\
\hline Petroselinum crispum convar. radicosum & Parsley root & 0.21 & 2.27 & - & $\mathrm{x}$ \\
\hline Petroselinum crispum convar. crispum & Parsley & 0.1 & 1.15 & - & $\mathrm{x}$ \\
\hline Phaseolus vulgaris ssp. vulgaris var. nanus & Dwarf bean & 8.75 & 8.88 & 1.51 & $\mathrm{x}$ \\
\hline Pisum sativum ssp. sativum convar. axiphium & Pea & 0.22 & 0.35 & - & $\mathrm{x}$ \\
\hline Raphanus sativus ssp. sativus & Radish & 0.74 & 2.02 & 0.62 & $\mathrm{x}$ \\
\hline Solanum tuberosum & Potato & 32.99 & 31.6 & - & $\mathrm{x}$ \\
\hline Allium tuberosum & Chinese chive & $\mathrm{x}$ & $\mathrm{x}$ & $\mathrm{x}$ & + \\
\hline Anethum graveolens var. hortorum & Dill & $\mathrm{x}$ & $\mathrm{x}$ & $\mathrm{x}$ & + \\
\hline $\begin{array}{l}\text { Brassica oleracea ssp. oleracea convar. botrytis var. } \\
\text { italica }\end{array}$ & Broccoli & $\mathrm{x}$ & $\mathrm{x}$ & $\mathrm{x}$ & 2.29 \\
\hline Cicer arietinum & Chick pea & $\mathrm{x}$ & $\mathrm{x}$ & $\mathrm{x}$ & 0.07 \\
\hline Coriandrum sativum & Coriander & $\mathrm{x}$ & $\mathrm{x}$ & $\mathrm{x}$ & + \\
\hline Cucurbita maxima & Pumpkin & $\mathrm{x}$ & $\mathrm{x}$ & $\mathrm{x}$ & 27.52 \\
\hline Eruca sativa ssp. sativa & Ruccola & $\mathrm{x}$ & $\mathrm{x}$ & $\mathrm{x}$ & 1.45 \\
\hline Glycine max & Soybean & $\mathrm{x}$ & $\mathrm{x}$ & $\mathrm{x}$ & 0.43 \\
\hline Ocimum basilicum & Basil & $\mathrm{x}$ & $\mathrm{x}$ & $\mathrm{x}$ & + \\
\hline Origanum vulgare ssp. vulgare & Oregano & $\mathrm{x}$ & $\mathrm{x}$ & $\mathrm{x}$ & + \\
\hline Physalis peruviana & Cape gooseberry & $\mathrm{x}$ & $\mathrm{x}$ & $\mathrm{x}$ & 0.48 \\
\hline Satureja hortensis & Savory & $\mathrm{x}$ & $\mathrm{x}$ & $\mathrm{x}$ & + \\
\hline Solanum melongena & Egg plant & $\mathrm{x}$ & $\mathrm{x}$ & $\mathrm{x}$ & 1.42 \\
\hline Zea mays & Corn & $\mathrm{x}$ & $\mathrm{x}$ & $\mathrm{x}$ & 7.01 \\
\hline$+\ldots$ herbs & & & & & 0.68 \\
\hline Subtotal & & 163.02 & 149.95 & 16.96 & 41.34 \\
\hline Total for LIS and HIS & & 163.02 & & 208.25 & \\
\hline
\end{tabular}

+ , Total quantity of all species with ' + ' $=0.68 \mathrm{~kg} \mathrm{subplot}^{-1}$.

- , No additional individuals sown.

$\mathrm{x}$, Species not sown/not planted.

The rows of plant species were divided into four subsamples of equal length per subplot and all data on harvested produce of those species sown by the farmer were recorded per subsample.

An experimental design based upon randomly distributed replications of low- and high-intensity management was not possible because of the small size of the subplots, the limited number of subplots at Roter Berg and because of the fact that all except two subplots were already reserved by the self-harvesters. Differences in yields of those species sown by the farmer between the two subplots are therefore not analyzed statistically.

After harvest, the produce was cleaned and/or washed and then dried with a rag from washing water at the plot. It was then weighed and the price of the produce for that species was investigated at a randomly chosen organic 
produce shop (price for organic produce) and at a randomly chosen supermarket (price for conventional produce) close to the Selbsternte plot in Vienna. The yield $(\mathrm{kg})$ was multiplied by the organic and the conventional marked prices of the respective produce and quantity at the selected shops.

\section{Survey of Selbsternte self-harvesters}

In 200128 female and 3 male self-harvesters, and one family, were registered for subplots at Roter Berg (all 32 referred to subsequently as self-harvesters). In addition, two subplots were registered for the experiment (total: 34 subplots). Three self-harvesters never did show up and two had to stop their activities during the vegetation period due to health problems. Cultivated species at their subplots developed badly due to the lack of water and the growth of weeds. Produce of their subplots was not harvested. Structured interviews using pre-tested pre-coded questionnaires ${ }^{15}$ were conducted with those 27 self-harvesters who worked at their plots at the Selbsternte plot Roter Berg until the end of the season.

The self-harvesters were between 30 and 50 years old, married or lived with a partner and had a high school diploma. Half of the users had children. Two-thirds had spent their youth in cities and only one-third in the countryside, but three-quarters reported having helped, at least for a while, in a garden or on a farm at some point in their childhood. Sixty percent of the predecessors of the users had a farm, nursery or a home garden where some vegetables were grown. Eight self-harvesters participated in Selbsternte for the first time in 2001, eight for the second time, and nine for the third time. Two of the self-harvesters had more experience than did all the others.

\section{Survey of the Selbsternte farmers}

Pre-tested interviews with pre-coded and with open questions ${ }^{15}$ took place with eight Selbsternte farmers in January 2002. Anonymity was guaranteed in the interviews. These Selbsternte farmers own between 30 and 140 ha of land. Seven of the farms are managed full time, 1 part time, but all of them are managed by the farmers' families. The size of the Selbsternte plots is between 0.02 and 3.3 ha. In addition to the Selbsternte activities, farmers keep animals and manage arable crops. Only one farmer grows vegetables in addition to those of the Selbsternte plot.

\section{Elicitation of the history of the concept}

Semi-structured interviews ${ }^{15}$ were conducted with the founder of the Selbsternte company, Mrs R. Bruno, who has worked with the concept since it emerged. These interviews consisted of information on the history of the concept, as well as of her experience with it, and took place between January 1999 and December 2002. To explain the characteristics and history of the concept, the results of these interviews have already been presented in the introduction of this paper.

\section{Results}

\section{Survey at the experimental plots}

At both subplots, work was done in the Selbsternte period (136 days) on 51 days each (2.6 visits per week per subplot). At the LIS subplot $24.2 \mathrm{~h}$ ( $28 \mathrm{~min}$ per visit) and at the HIS subplot $38.9 \mathrm{~h}$ ( $46 \mathrm{~min}$ per visit) of work were invested on these days. At both subplots the greatest proportion of time was used for irrigation (LIS, $12.2 \mathrm{~h}$; HIS, $17.5 \mathrm{~h})$. More time was dedicated for sowing/planting and soil management (preparing the soil for seeding or planting of additional plants) at the HIS than at the LIS subplot, due to the additional activities realized at the HIS subplot (Table 3, Fig. 4).

Investments were US\$184 for the LIS and US\$259 for the HIS subplot. The biggest proportion was due to the rental fee for each subplot (US\$182). The higher costs of the HIS subplot resulted from the expense of the additionally sown/planted species (US\$56) and the necessary additional equipment (US\$21; e.g., for posts supporting tomatoes) (Table 3 ).

The total harvest of fresh produce for the plants sown/ planted by the farmers was $163 \mathrm{~kg} \mathrm{subplot}^{-1}$ from the LIS and $150 \mathrm{~kg} \mathrm{subplot}^{-1}$ from the HIS subplot. The highest yields of those plants sown/planted by the farmer (mean for LIS and HIS) were achieved with squash (Cucurbita pepo; $32.55 \mathrm{~kg} \mathrm{subplot}^{-1}$ ), potatoes (Solanum tuberosum, $32.29 \mathrm{~kg} \mathrm{subplot}^{-1}$ ), Swiss chard (Beta vulgaris ssp. vulgaris convar. cicla var. cicla, $19.13 \mathrm{~kg} \mathrm{subplot}^{-1}$ ), carrots (Daucus carota ssp. sativus, $15.03 \mathrm{~kg} \mathrm{subplot}^{-1}$ ), pumpkins (Cucurbita moschata, $13.91 \mathrm{~kg} \mathrm{subplot}^{-1}$ ), tomatoes (Lycopersicon esculentum var. esculentum; $13.78 \mathrm{~kg}$ subplot $^{-1}$ ) and dwarf beans (Phaseolus vulgaris ssp. vulgaris

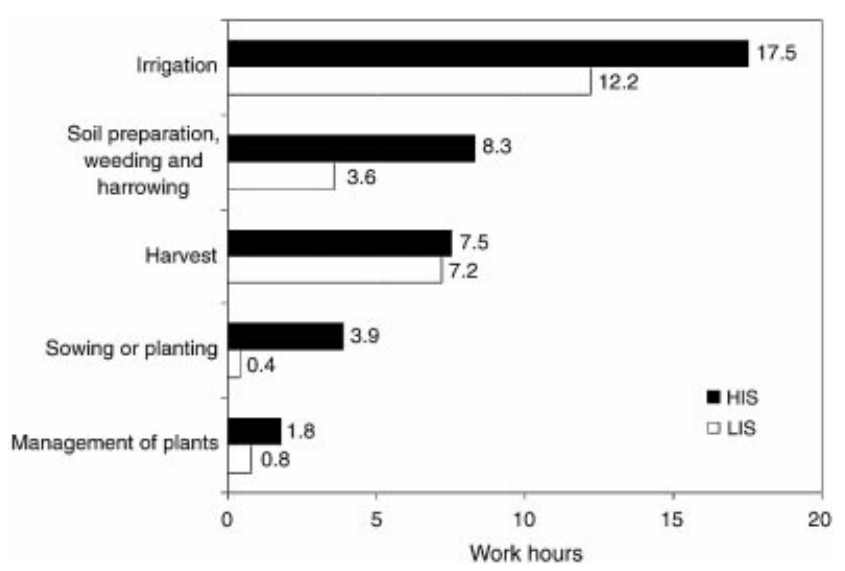

Figure 4. Labor input (total work hours) for the management practices at the low-intensity (LIS) and the high-intensity (HIS) experimental subplots at the Selbsternte plot, Roter Berg in Vienna. 
Table 3. Results of the survey at the experimental subplots.

\begin{tabular}{|c|c|c|c|c|}
\hline Topic & Parameter observed & Unit & LIS & HIS \\
\hline \multirow[t]{3}{*}{ Species } & Number of plant species sown/planted by the Selbsternte farmer & Number & 20 & 20 \\
\hline & Number of plant species, where additional individuals were sown at the HIS & Number & 0 & 6 \\
\hline & Number of additional plant species sown/planted at the HIS & Number & 0 & 14 \\
\hline \multirow[t]{4}{*}{ Work } & Duration of Selbsternte vegetation period & Days & 136 & 136 \\
\hline & Days working at the subplots $=$ number of visits & Number & 51 & 51 \\
\hline & Total work time (see Fig. 4 for details) & Hours & 24.2 & 38.9 \\
\hline & Work time/visit & Minutes & 28 & 46 \\
\hline \multirow[t]{5}{*}{ Cost } & Cost: total & US\$ & 184 & 259 \\
\hline & Cost: details & US\$ & & \\
\hline & Rental fee & & 182 & 182 \\
\hline & Additional seeds/plantlets & & 2 & 56 \\
\hline & Tools/equipment & & 0 & 21 \\
\hline \multirow[t]{3}{*}{ Yield } & Total fresh yield of species sown by farmer & $\mathrm{kg}$ subplot ${ }^{-1}$ & $163^{l}$ & $150^{l}$ \\
\hline & Total fresh yield of additional individuals and additional species & & - & 58 \\
\hline & Total yield all individuals and all species & & 163 & 208 \\
\hline \multirow[t]{9}{*}{ Value of harvest } & Value of produce sown by farmer & US\$ & & \\
\hline & Conventional prices & & 219 & 214 \\
\hline & Organic prices & & 522 & 495 \\
\hline & Value of additionally sown/ planted species/individuals & US\$ & & \\
\hline & Conventional prices & & 0 & 150 \\
\hline & Organic prices & & 0 & 271 \\
\hline & Value of produce total & US\$ & & \\
\hline & Conventional prices & & 219 & 364 \\
\hline & Organic prices & & 522 & 766 \\
\hline \multirow[t]{6}{*}{ Net profit } & Net-profit for total harvest (value minus costs) & US\$ & & \\
\hline & Conventional prices & & 35 & 105 \\
\hline & Organic prices & & 338 & 507 \\
\hline & Net profit per work hour & $\mathrm{US} \$ \mathrm{~h}^{-1}$ & & \\
\hline & Conventional prices & & 1.5 & 2.7 \\
\hline & Organic prices & & 14.0 & 13.0 \\
\hline
\end{tabular}

LIS, low-intensity subplot; HIS, high-intensity subplot.

${ }^{I}$ Details of yields see Table 2 .

var. nanus, $8.81 \mathrm{~kg} \mathrm{subplot}^{-1}$ ). Together with the additionally introduced plants, the HIS subplot yielded $208.25 \mathrm{~kg}$ of fresh produce (Table 3).

The monetary value of the total of all harvested produce of those plants sown/planted by the Selbsternte farmer was US\$219 for the LIS subplot, and US\$214 for the HIS subplot for conventional prices, and US\$522 for the LIS and US\$495 for the HIS subplots for organic prices. At the HIS subplot the value of the harvest of the additionally sown/planted produce was US\$150 for conventional and US\$271 for organic prices. The total value of the harvest at the HIS subplot was US\$364 for conventional and US\$766 for organic prices. The highest net-profit was achieved at the HIS subplot for organic prices (US\$507) and the highest net profit per work hour was achieved at the LIS subplot for organic prices, with US\$14 per invested hour of labor (Table 3, Fig. 5).

\section{Survey of the Selbsternte self-harvesters}

The 27 self-harvesters interviewed live, on average, $1.8 \mathrm{~km}$, or about $10 \mathrm{~min}$, away from the Selbsternte plot. Twenty- six self-harvesters bridged the distance on foot or by bicycle. Only one of the self-harvesters traveled exclusively by car. Seven self-harvesters, who usually went on foot or by bicycle, used the car only if they had to transport large quantities of harvested plants.

Of the 27 self-harvesters interviewed, 18 self-harvesters rented subplots of $40 \mathrm{~m}^{2}$, and 9 rented $80 \mathrm{~m}^{2}$ subplots. They worked at their subplots, on average, 2.4 times a week. Every visit took them, on average, $1.5 \mathrm{~h}$. Visits reported by the self-harvesters cover the total time of presence at the plot, i.e., work time at their subplots and time for leisure activities at the plot. On average, self-harvesters reported having been at their subplot for $68 \mathrm{~h}$ between May 18 and October 31. For half of the respondents, time invested was as they had expected, for one-quarter it was less, and for one-quarter it was more time than expected.

The most frequent activity was irrigating. Seventeen users reported irrigating at least twice a week. The other ten reported less frequent irrigation (between 1 and 6 times a month). Weeding was done by all of them, and more than half (14) weeded between once and three times monthly. The rest did it more frequently. Harrowing 


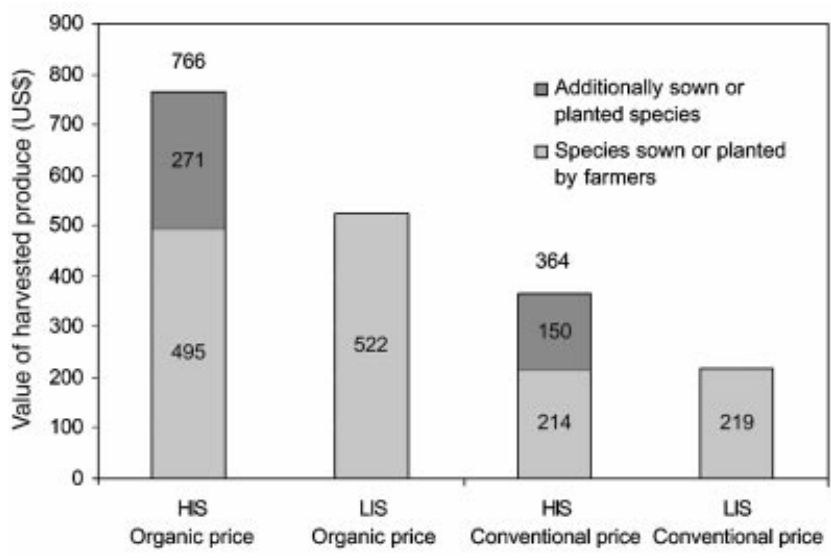

Figure 5. Value of the total fresh harvest calculated according to organic or to conventional prices, in US\$, at the both experimental plots (HIS = high-intensity subplot; LIS = low-intensity subplot) at the Selbsternte plot, Roter Berg in Vienna.

between rows and in rows between the plants was done by 24 self-harvesters. The majority (17) did this less than three times a month. Harvesting was done at least once a week.

Nine of the self-harvesters believed they invested more cash in the subplot than the value of the harvest yields, and 14 believed they invested less. Twenty self-harvesters harvested all ripe produce; seven left ripe produce at the subplot without harvesting it. Twenty-six also reported having given produce away to friends, relatives, other selfharvesters and passers-by as a gift. Reasons given for leaving ripe produce at the subplot or for giving it away as a gift were the large amount of harvested produce or the dislike of a certain plant species. Neither barter nor commercialization was reported or observed.

All self-harvesters saw the rental of a subplot and the work as an activity of leisure. When asked about what selfharvesters actually did at the plot, 16 self-harvesters reported having done things in addition to their subplot management. These 16 self-harvesters mentioned activities (multiple answers were possible) such as resting and meditating (33\%), talking with other self-harvesters (24\%), picnicking (12\%), playing with children (9\%), walking around or nature watching (both 6\%), reading a book, sunbathing or taking photographs (all 3\%).

Almost all users (24) said they received support in their management of the subplot: the partner, boy- or girlfriend, or husband or wife were the most frequently mentioned helpers (in 15 cases), followed by friends (in 12 cases), children (in 9 cases) and parents (in 5 cases). Several selfharvesters report that several of the persons mentioned helped, but on different occasions. Nineteen self-harvesters got help during their work from other self- harvesters at the plot, mostly from neighbors (12) and the rest from nonneighbors (7). This help concerned mostly irrigation during vacation periods. During the interviews, some cases were reported where border rules were not explained carefully and, consequently, these friends worked at or harvested the wrong subplots. Twenty-six of the self-harvesters reported having invited friends and relatives who were not familiar with the Selbsternte concept, to visit the plot.

All self-harvesters reported having visited the subplots of other users. During such visits, the general appearance of the subplots, and specific practices used, were observed and the diversity of plant species was assessed. The observation of differences in yields was reported by only three selfharvesters as something to be assessed during such a visit. Eighteen self-harvesters reported having learned something through talks and observations from these visits, mostly from their neighbors. They learned about weeding, mulching, about the handling of tomatoes, harrowing and about the use of allelopathic effects.

More than half (14) of the self-harvesters reported 'trying something new' at their subplots. The most frequently mentioned innovation for them (multiple answers were possible per person) was growing an unknown species (14 self-harvesters), testing plants as repellents against pests (3), testing effects of mixed cropping, improving the soils with alternative additives (for both, 2), or, e.g., testing different sowing dates, while taking into account the influence of moon, mulch, plant extracts and so on (one self-harvester for all three).

However, there was one clearly visible innovation, first implemented by one self-harvester, that spread through the subplots during the vegetation period and was not mentioned by anybody. This was the use of 1.5 liter plastic bottles for irrigating tomatoes. The bottom of the bottle was cut away, the bottles turned around and stuck (with the bottle neck) into the soil. Water was added to this kind of funnel until it no longer ran from the bottle into the soil, i.e. until the funnel was full of water. The bottle served as a kind of reservoir for 2 or 3 days, releasing the water slowly. While conversing at the plot, consumers who used this kind of irrigation reported advantages such as: direct delivery of water to the roots (i.e., less water dispersed around the plants and therefore less weed growth) and less stress for the self-harvester in getting to the subplots immediately on hot days for the purpose of irrigation.

Twenty-five of the self-harvesters sowed/planted 54 additional plant species or additional individuals of species already sown by the Selbsternte farmer. Additional plants were sown where others had been harvested, at the edges of the subplot or between the rows of the already planted species. The most frequently introduced additional individuals of already sown/planted species were iceberg lettuce (Lactuca sativa var. capitata), dwarf bean (Phaseolus vulgaris ssp. vulgaris var. nanu) and carrot (Daucus carota ssp. sativus).

The most frequently introduced additional new species were broccoli (Brassica oleracea ssp. oleracea convar. botrytis var. italica), basil (Ocimum basilicum), ruccola (Eruca sativa ssp. sativa) and dill (Anethum graveolens var. hortorum). 
Seeds/plantlets of these additional 54 species were distributed by the Selbsternte company (61\%), shops $(12 \%)$, friends $(8 \%)$ and mail delivery companies $(6 \%)$ or they came from the self-harvesters' own subplots from previous years $(8 \%)$. In $5 \%$ of the cases, the source was not reported. Individual self-harvesters introduced up to 25 new species, but the majority introduced between 6 and 15 . Twenty self-harvesters reported having bought only organic seeds/plantlets, while five report having bought organic seeds/plantlets, but also having bought one or the other species from conventional sources.

The most frequently mentioned reasons for sowing/ planting additional species $(n=25$ self-harvesters reported on all additionally sown species) were the preferred taste of a certain species $(37 \%)$, curiosity $(23 \%)$, contribution to health $(18 \%)$, aesthetics $(15 \%)$, allelopathic effects $(4 \%)$ and the role in the control of pests and diseases $(3 \%)$.

Six users related some species to specific events in their youth and nine users related some species to an experience in a foreign country. One of them was German and he reported having introduced chives (Allium schoenoprasum ssp. schoenoprassum), peppermint (Mentha $\times$ piperita), lemon balm (Melissa officinalis), savory (Satureja hortensis) and dill. One self-harvester was from Iran and he reported having introduced chick peas (Cicer arietinum). Another self-harvester, having been a resident in Japan, reported having sown additional Chinese cabbage (Brassica rapa ssp. pekinensis), edible crown daisy (Chrysanthemum coronarium) and purple shiso (Perilla frutescens).

\section{Survey on the Selbsternte farmers}

All eight farmers reported that the consultancy provided by the Selbsternte company was helpful in establishing their activities. Farmers reported activities such as obtaining technical information, marketing of the concept, organization of meetings and the provision of organic seeds through their license fees as the main benefits of their participation in the Selbsternte company.

Five farmers had contact with the other Selbsternte farmers, either at the beginning or later in their Selbsternte activities. They reported that exchanging information and exchanging technical equipment were the main reasons for the contact.

Four farmers expected more self-harvesters at the start of their Selbsternte activity and all except one farmer want to attract more users in the coming years. When asked what they would do differently if they could begin again, they reported wishing to have made better cost/benefit calculations (2), to have reduced expensive marketing activities (1), to have offered only $80 \mathrm{~m}^{2}$ subplots instead of a choice of sizes (1) and, because it is too labor intensive, to have done only the sowing, leaving the transplanting of seedlings to the self-harvesters (1). Farmers estimated the value of produce harvested by the self-harvesters as somewhere between 'less than US\$100' and 'up to US\$500'. None of the farmers could give a figure for the value of the subplot output based upon previous calculations of the same.

The motivating factors in establishing Selbsternte plots, as reported by all the farmers, were, primarily, personal (direct contact with self-harvesters, diversification of work to be done, fun), and only then economic.

Only three farmers reported that the income from Selbsternte allowed a satisfactory return on the investments made for Selbsternte. The contribution of Selbsternte varied between 0 and $30 \%$ of the total farm income, according to the perception of the farmers. Those farmers who sell their own produce from the farm gate (7) emphasized the fact that Selbsternte self-harvesters did actually buy produce at the farm gate or from the farm's own shop and therefore contributed to the income not also with their Selbsternte fees but with their weekly spending for produce bought from the farmers.

In total, the farmers sowed or planted 25 plant species. Seeds came from organic seed producers (e.g., the organic seed propagation and retailing company Reinsaat). Plantlets originated from organic seeds and were, depending on the species, bought from organic nurseries or grown at the Selbsternte farm by the farmers themselves. Criteria in selecting certain species were personal observations on yields, requests by self-harvesters and recommendations made by the Selbsternte consultant. Only one farmer made a cost calculation to determine the rental fee of a subplot. The other seven farmers adjusted their prices to the fees charged by the Selbsternte company for its subplots and according to recommendations of colleagues.

The problems reported with Selbsternte are those currently challenging the management of organic farms as well (pressure of weeds, pests and diseases, supply of nutrients). But more frequently farmers reported the following specific technical and social problems.

- The control of EC-Regulation 2092/91, which requests the use of organic seeds/plantlets in subplots, is difficult to manage with self-harvesters who continuously sow seeds/plant plantlets from unidentified sources.

- Self-harvesters who do not weed well may risk weed infestation at other subplots and may be the cause of conflict between self-harvesters.

- Deposition of garbage at the plot by self-harvesters affects the appearance of the plot.

- Low technical skill and self-harvester knowledge of gardening practices (e.g., frequent and long irrigation), which then lead to effects that are a source of complaints (e.g., strong growth of weeds).

- Theft of ripe produce or even of tools in a few cases. All eight farmers reported that during the course of the vegetation period, many questions from self-harvesters arose and were then addressed directly to the farmers. In many cases, these questions not only covered technical topics matching the farmers' knowledge (time of harvest of certain species, techniques for pest management, etc.), but also related to topics such as processing, storage and cooking. In addition, all of the farmers reported that they 
were confronted with problems concerning the social dynamics at the plot (e.g., self-harvester anger about the behavior of neighboring self-harvesters).

As a main success factor, all of the farmers reported the intensity of relations between the self-harvesters and the farmers. At one farm, the farmer gave a subplot for free to an experienced self-harvester, who is present almost every day at the plot and who serves as a kind of representative for the farmer at the plot.

\section{Conclusion}

Our results show that self-harvesters who manage a subplot intensively can harvest up to $208 \mathrm{~kg}$ of fresh produce, with a value of US\$766 from a subplot of $80 \mathrm{~m}^{2}$. This is above the value expected by the farmers who offer subplots and above the value of US\$538 reported from subplots in Witzenhausen, Germany ${ }^{14}$. This result might help farmers to better advertise the concept.

The germination rate and the juvenile growth (not quantified in this survey) of the plants on the experimental subplots, as also seen in some other subplots at Roter Berg, was lower than expected, due to failures in plot preparation by the farmer. Taking into account that other subplots at Roter Berg and subplots at other sites (e.g., Mödling) showed much better developed plants, it is evident that higher yields of harvested produce can be expected with better growing conditions.

Nevertheless, we believe that the importance of the data on yields and value of produce should not be overestimated as, for most species, they come as an excess of produce over a relatively short period of time. Self-harvesters probably would not have spent an equivalent amount of money to purchase the same amount of produce. The lack of sequential plantings, which could avoid the oversupply of produce at a particular time, is a weakness of the system, in which the entire plot is planted at once. Nevertheless, self-harvesters do not see this excess as useless surplus, nor would they sell it. Self-harvesters deal with this excess by organizing dinners with a large number of relatives and friends, by processing produce (pickling, making sauces, drying, etc.) and by giving it away in barter or as a gift.

The better yield performance of the HIS subplot and the value of produce is due to the additionally introduced plants. Introducing new plants is self-harvesters' favorite area of experimentation. Nevertheless, control of the organic origin of seeds and plantlets is a challenge not easily met by farmers.

In managing a Selbsternte plot, the farmers involved in the project report the need for close communication with self-harvesters, which not only helps to attract them as clients (marketing), but also provides prior precise and accurate information on necessary technical and social details (e.g., regulations on the 'do's' and 'don'ts'). It is important to provide information that helps to avoid unachievable expectations, secures appropriate social relations between self-harvesters, and-as the plots are certified organic-ensures that substances prohibited in organic farming are not used.

During the course of the vegetation period, many questions arise on the part of self-harvesters. Most farmers have, in our observation, only limited experience and training in the handling of these communication processes. In addition, the huge amount of time necessary for selfharvester relations competes with other activities on the farm. Successful management of Selbsternte plots therefore needs a concept of communication, care and training for self-harvesters that would reduce the workload for farmers while ensuring good relations with self-harvesters.

People frequently accompany the authorized selfharvesters (friends, children) but they are not involved in the communication process. These guests might be a risk if they counter the established regulations, and situations such as these can negatively influence relations between neighbors.

The concept of Selbsternte needs not only proper social skills but also special technical training for farmers prior to the start of the project. Only one farmer grows vegetables in addition to the Selbsternte activities, and no farmer has experience with small-scale horticulture. The participating farmers are growers of arable crops and are used to thinking on a larger scale of agriculture than are self-harvesters, gardeners or horticulturists.

On an arable plot measuring one or more hectares, a failure to sow or germinate, which has an impact on only a few centimeters of a row, might have no real impact for the farmer, if at all. At a Selbsternte plot, the lack of a species or of some plant individuals in a certain part of the subplots, resulting from technical errors, leads to adverse social dynamics and can be difficult for the farmer to handle. Therefore, an adaptation of thought, management and of technical equipment to small-scale horticulture is necessary, and farmers must be trained accordingly.

Some species make it necessary to establish a plant nursery in a greenhouse. Some farmers do this for certain species at their farms. The selection of the appropriate species, time of sowing, irrigation, pest management and manipulation of the microclimate in the greenhouse turns out to be a sophisticated task for inexperienced farmers, with possible economic losses for them. Therefore most farmers outsourced the cultivation of plantlets.

Irrigation was carried out whenever self-harvesters believed it was necessary, according to non-professional decision criteria. According to the Selbsternte consultants, watering is usually done too often and for too long, resulting, under the usually dry growing conditions around Vienna, in good performance of crops but also intense growth of weeds. This resulted in a high workload for selfharvesters with respect to weeding. Occasionally, and by merit of their agricultural experience, some farmers do the watering with overhead sprinklers in order to raise irrigation efficiency.

The need for the training of farmers, for the exchange of experience between farmers, for accompanying self- 
harvester education and for advertising is easier to handle on a common or outsourced level than on an individual level. To secure proper advice when needed, higher fees for subplots and higher license fees were discussed in the Selbsternte company, but were not seen as viable. If this cannot be realized, honorary advisors that are nominated on the basis of experience, and referred to as 'senior' selfharvesters, might be one valuable solution.

The proponents of Selbsternte are convinced that this concept leads to ecological, economic and social benefits, which will help to design a sustainable food supply system for small, medium and large cities. Our data allow for the prior formulation of an evidence-based hypothesis on which further testing may be based.

\section{Hypothesis of possible ecological benefits}

- The high amount of produce harvested, and the short distance between the residential areas of the selfharvesters and the plot, may help to reduce the duration and frequency of individual tours to shopping malls by car.

- The concept of Selbsternte leads to higher agrobiodiversity in the urban area, where this concept is practiced; self-harvesters actively enrich the subplot by seeding/planting additional species. These might be endangered species or cultivars, and therefore the concept might be a valuable element for strategies of in situ conservation of agrobiodiversity.

- The produce so harvested does not need packaging and therefore package production and deposition can be reduced for the quantity harvested.

\section{Hypothesis of possible economic benefits}

- The monetary value of the vegetables harvested is higher than the money invested by the plot owner. Selbsternte plots help to reduce costs for organic nutrition, compared to self-harvester purchases at organic produce shops.

- Local organic gardeners, tool retailers and other providers of necessary and allowable substances benefit from the demand of self-harvesters who have rented Selbsternte plots.

\section{Hypothesis of possible social benefits}

- Selbsternte initiates new networks of communication and collaboration between inhabitants of residential areas, who have not yet met.

- Selbsternte plots serve as meeting points for people, allowing for the exchange of opinions, information and knowledge (including that of organic gardening).

- Work at subplots helps participants to relax, meditate and rest after daily business.

- Parents consciously use the work at the subplot to educate their children in horticulture, plant species and related topics.
- Consumers get involved in primary agricultural production. They therefore better understand the risks and challenges that farmers face, as well as the pleasure involved.

Up to now only a few descriptive questions about Selbsternte have been addressed. More quantitative data on the ecological, economic and social impact of Selbsternte are needed to test these hypotheses. Selbsternte subplots can be understood as small experimental stations where self-harvesters merge traditional horticultural techniques with urban ideas on permaculture, sustainable land use and participatory farming. The outcomes of this participatory process of innovation have to be assessed with regard to their potential value for the improvement of urban agriculture, but also for the development of organic farming in general.

Acknowledgements. We thank Mrs Regine Bruno, founder of the Selbsternte company, for support in the compilation of necessary data on the history of Selbsternte and for the chance to establish experimental subplots at the Selbsternte plot, Roter Berg. We are especially grateful to Miguel Altieri, who accompanied us on a visit to Selbsternte plots in Vienna and who encouraged us to start research on this topic. We also thank the anonymous reviewers and the editors of RAFS, as well as Cristina Flitner, for valuable comments on previous versions of the manuscript of this paper.

\section{References}

1 Bakker, N., Dubbeling, M., Gündel, S., Sabel-Koschella, U., and Zeeuw, H.d. (eds). 2000. Growing Cities, Growing Food Urban Agriculture on the Policy Agenda. German Foundation for International Development, Feldafing, Germany.

2 Mougeot, L.J.A. 2000. Urban agriculture - definition, presence, potentials and risks. In N. Bakker, M. Dubbeling, S. Gündel, U. Sabel-Koschella, and H.d. Zeeuw (eds). Growing Cities, Growing Food. German Foundation for International Development, Feldafing, Germany. p. 1-42.

3 Smit, J., Ratta, A., and Nasr, J. 1996. Urban Agriculture: Food, Jobs and Sustainable Cities. United Nations Development Programme, New York, USA.

4 Moustier, P. 1996. Organisation in the Brazzaville vegetable market. PhD thesis, University of London, UK.

5 Armar-Klemesu, M. 2000. Urban agriculture and food security, nutrition and health. In N. Bakker, M. Dubbeling, S. Gündel, U. Sabel-Koschella, and H.d. Zeeuw (eds). Growing Cities, Growing Food. German Foundation for International Development, Feldafing, Germany. p. 99-117.

6 Deelstra, T. and Girardet, H. 2000. Urban agriculture and sustainable cities. In N. Bakker, M. Dubbeling, S. Gündel, U. Sabel-Koschella, and H.d. Zeeuw (eds). Growing Cities, Growing Food. German Foundation for International Development, Feldafing, Germany. p. 43-65.

7 Grünsteidel, I. 2000. Community Gardens - Grüne Oasen in den Ghettos von New York. In E. Meyer-Renschhausen and A. Holl (eds). Die Wiederkehr der Gärten. Studienverlag, Innsbruck, Austria. p. 125-139.

8 Gröning, G. 2000. Kampfesmutige Laubenpieper Kleingärten und Politk in Berlin zwischen 1985 und 1995. In E. Meyer-Renschhausen and A. Holl (eds). Die Wiederkehr der Gärten. Studienverlag, Innsbruck, Austria. p. 140-161. 
9 Akemine, T. and Pestemer, R. 2002. Die SelbstversorgungsGuerilla in Japan. In E. Meyer-Renschhausen, R. Müller, and P. Becker (eds). Die Gärten der Frauen - Zur sozialen Bedeutung von Kleinstlandwirtschaft in Stadt und Land weltweit. Centaurus, Herbolzheim, Germany. p. 178-188.

10 Garnett, T. 2000. Urban agriculture in London: rethinking our food economy. In N. Bakker, M. Dubbeling, S. Gündel, U. Sabel-Koschella, and H.d. Zeeuw (eds). Growing Cities, Growing Food. German Foundation for International Development, Feldafing, Germany. p. 477-500.

11 Galanti, G. 2002. Integrating ecological practices into urban garden management in developing countries. Urban Agriculture Magazine 6:15-16.
12 Van Hirtum, M., Goewie, E., Getachew, Y., and Van Veenhuizen, R. 2002. Transition to ecological urban agriculture - a challenge. Urban Agriculture Magazine 6:1-3.

13 Böhnhardt, J., Fennekohl, K., Engelhardt, H., Winnicki, T., and Hess, J. 1999. Gemüse selbst ernten. University of Kassel, Kassel-Witzenhausen, Germany.

14 Wortmann, A. 2000. Gemüse selbst ernten auf der Domäne Frankenhausen: Ein Beitrag zum nachhaltigen Konsum. Masters thesis, University of Kassel, Kassel-Witzenhausen, Germany.

15 Bernard, H.R. 2002. Research Methods in Anthropology Qualitative and Quantitative Approaches. Altamira Press, Walnut Creek, California, USA. 